\title{
PENGARUH MOTIVASI DAN KETERAMPILAN BERKOMUNIKASI TERHADAP PRESTASI BELAJAR MAHASISWA PADA TUTORIAL ONLINE BERBASIS PENDEKATAN KONTEKSTUAL PADA MATAKULIAH STATISTIKA PENDIDIKAN
}

\author{
Mery Noviyanti (meryn@ut.ac.id) \\ FKIP-UT, Jl. Cabe Raya, Pondok Cabe, Pamulang, Kota Tangerang Selatan
}

\begin{abstract}
Student' achievement for Statistics for education course at Universitas Terbuka (UT) is relatively low. Students need learning process that can increase learning motivation. Contextual approach is a learning process where students can understand the concept through its application in daily life which supposedly will increase learning motivation. Online tutorial is one of learning support services provided by the UT via the internet. By utilizing the discussion forums, initiation material, assignments and exercises, students can improve their communication skills so as to facilitate their learning. This article is based on the research which aimed to find out how motivation and communication skills influenced the learning achievement in online tutorials with contextual approach on Statistics for education course. Field trials were carried out in 36 undergraduate students who followed the online tutorials. The independent variable is motivation and communication skills, while the dependent variable is the learning achievement. Data were taken through questionnaires and observation and processed by means of regression test. The results showed that: a) motivation affect learning achievement by $88.7 \%, b$ ) communication skills has a positive effect on learning achievement by $74.7 \%$, and c) the influence of motivation and communication skills to the learning achievement was $89.7 \%$.
\end{abstract}

Keywords: communication skills, learning motivation

Statistika adalah metode ilmiah yang mempelajari pengumpulan, pengaturan, perhitungan, penggambaran dan penganalisaan data, serta penarikan kesimpulan. Statistika terdiri dari berbagai macam penerapan, salah satunya dalam bidang pendidikan yang dinamakan Statistika Pendidikan yang disediakan Fakultas Keguruan dan IImu Pendidikan-Universitas Terbuka (FKIP-UT)

Prestasi belajar mahasiswa FKIP-UT mempunyai masalah terkait dengan matakuliah Statistika Pendidikan. Data dari Pusat Pengujian UT tahun 2010, menunjukkan bahwa nilai matakuliah Statistika Pendidikan program Non Pendas FKIP-UT untuk masa registrasi 2010.1 rendah. Hal tersebut terlihat dari jumlah nilai dibawah $\mathrm{C}$ ada lebih dari $50 \%$. Berdasarkan wawancara dengan 10 orang mahasiswa, mereka mempunyai kesulitan dalam menyusun data ke dalam bentuk tabel dan diagram, menganalisis dan menginterprestasikan data tersebut. Selain itu mereka mempunyai kesulitan mempelajari materi kurva normal dan kurva lainnya karena tidak diterapkan dalam kehidupan sehari-hari.

Sebagai perguruan tinggi jarak jauh UT menyediakan layanan bantuan belajar di antaranya adalah tutorial online, yang merupakan aplikasi dari E-learning. Namun tutorial online untuk matakuliah Statistika Pendidikan belum berjalan dengan baik. Hal tersebut diperkuat oleh Noviyanti (2006) yang menyebutkan bahwa partisipasi mahasiswa FKIP-UT mengikuti tutorial online kurang dari 5\%. Masih belum maksimalnya partisipasi mahasiswa dalam tutorial online memunculkan 
dugaan bahwa terdapat sejumlah faktor yang mempengaruhi tindak partisipasi mahasiswa, salah satunya adalah motivasi.

Selain motivasi, keterampilan berkomunikasi juga sangat penting untuk meningkatkan pemahaman mahasiswa terhadap suatu materi. Keterampilan berkomunikasi perlu dikembangkan supaya mahasiswa pandai bertanya, menyampaikan pendapat, berdiskusi, bergaul, dan memahami masalah kehidupan masyarakat. Komunikasi yang baik belum terlihat pada pelaksanaan tutorial online. Hal tersebut terlihat dari forum diskusi yang masih kosong pada pelaksanaan tutorial online sebelumnya. Tingginya keterampilan berkomunikasi mahasiswa dalam mengeluarkan ide, berdiskusi, dan memecahkan masalah diharapkan berdampak pada peningkatan prestasi belajar mahasiswa. Adanya keterampilan berkomunikasi yang dimiliki, mahasiswa dapat menggali lebih dalam pengetahuan mengenai materi yang ditutorialkan.

Berkaitan dengan penerapan E-learning pada tutorial online, E-learning merupakan kegiatan pembelajaran yang memanfaatkan jaringan (internet, LAN, WAN) sebagai metode penyampaian, interaksi, dan fasilitas serta didukung oleh berbagai bentuk layanan belajar lainnya (Brown, 2001). Pada pendidikan tinggi jarak jauh, proses pembelajaran sangat dipengaruhi oleh kemadirian mahasiswa pada saat belajar. Untuk membantu keberhasilan mahasiswa, institusi pendidikan jarak jauh menyediakan layanan bantuan belajar yang salah satunya adalah tutorial. Sejalan dengan perkembagan ICT selain tutorial tatap muka, tersedia pula tutorial dengan menggunakan internet yang dinamakan tutorial online. Jenis tutorial ini adalah salah satu contoh penerapan E-learning dalam proses tutorial.

Menurut Becta (dalam Hanafi, 2008), penggunaan E-learning dalam tutorial online dapat meningkatkan fleksibilitas dan kualitas belajar karena dapat: 1) menyediakan akses ke berbagai sumber belajar; 2) memberikan kontrol kepada mahasiswa atas kapan dan di mana mereka belajar; 3) memungkinkan mahasiswa untuk belajar dengan kecepatan mereka sendiri; 4) memberikan mahasiswa lingkungan belajar yang dapat disesuaikan untuk memenuhi pembelajaran kebutuhan masing-masing; 5) menciptakan lingkungan yang mempromosikan pendekatan aktif untuk belajar; 6 ) dukungan komunikasi meningkat antara tutor dan mahasiswa, dan di antara mahasiswa; 7) sering memberikan umpan balik dan tepat waktu misalnya melalui penilaian bantuan komputer, dan penguatan positif; 8) memotivasi mahasiswa melalui penggunaan bahan ajar interaktif dengan tepat; 9) mendukung dan mendorong kolaboratif pembelajaran; dan 10) mendorong mahasiswa untuk bertanggung jawab atas pembelajaran mereka sendiri.

Selanjutnya Pendekatan kontekstual atau Contextual Teaching and Learning (CTL) merupakan sebuah strategi pembelajaran yang tidak mengharuskan siswa menghafal fakta-fakta, tetapi sebuah strategi yang mendorong peserta didik mengkonstruksikan pengetahuan di benak mereka sendiri. CTL merupakan suatu konsepsi yang membantu guru mengaitkan konten mata pelajaran dengan situasi dunia nyata dan memotivasi peserta didik membuat hubungan antara pengetahuan dan penerapannya dalam kehidupan mereka (Trianto, 2009).

Pada tutorial Statistika Pendidikan, pendekatan kontekstual dapat dilakukan dengan menggunakan data yang dimiliki dan biasa digunakan dalam kehidupan sehari-hari. Misalnya dengan mempelajari ukuran lokasi (median, kuartil, desil dan persentil). Pemahaman mengenai ukuran lokasi sangat bermanfaat manakala mahasiswa membutuhkan nilai-nilai yang ada di suatu distribusi frekuensi mengenai penghasilan orang tua siswa. Misalnya ukuran lokasi dibagi menjadi empat bagian. Pembagian ini dibutuhkan berkaitan dengan dengan pembagian subsidi pemerintah di dunia pendidikan. Sebanyak 25\% dari penghasilan terendah akan diberikan beasiswa sebesar 
Rp.200.000,-, 25\% di atasnya akan diberikan Rp. 150.000,-, 25\% selanjutnya diberikan Rp.100.000,-, dan 25\% penghasilan tertinggi akan diberikan Rp.50.000,-. Dengan keperluan untuk menerapkan pengetahuan secara nyata seperti ini mahasiswa akan menggunakan ukuran lokasi untuk menjawabnya.

Contoh lain diantaranya adalah melibatkan mahasiswa untuk mempelajari tingkat variansi yang dihubungkan dengan harga saham. Mahasiswa dilibatkan seolah-olah sebagai investor. Harga saham yang sangat bervariasi lebih menarik investor yang berani mengambil resiko karena berpeluang besar dalam memperoleh keuntungan dengan konsekuensi kerugian yang besar pula. Oleh karena itu selain diperlukan nilai rerata, nilai variansi juga diperlukan untuk mewakili kelompok nilai.

Berkaitan dengan motivasi, dalam konteks belajar-mengajar motivasi dapat mengembangkan orientasi motivasi positif dalam belajar. Pendidik harus tahu bagaimana karakter dan kreativitas dari peserta didik yang beraneka ragam. Oleh karena itu, untuk membuat instruksi yang efektif dan menarik, seseorang harus memiliki pengetahuan tentang lingkungan kontekstual dan budaya yang mendefinisikan kepentingan dari peserta didik tersebut (Ames dalam Saxena, 2010)

Cocea (2010) memberikan tiga parameter yang digunakan untuk menilai motivasi peserta didik, di antaranya adalah usaha, kepercayaan diri, dan kemandirian. Sedangkan Smith (2008) mengusulkan Model ARCS (Attention, Relevance, Confidence, and Satisfaction) digunakan sebagai prinsip desain dalam rangka meningkatkan proses pembelajaran dengan motivasi. Model ini sangat cocok untuk menilai motivasi peserta didik melalui E-learning. Model ARCS dikembangkan oleh Keller dan Kopp (1987) sebagai jawaban pertanyaan bagaimana merancang pembelajaran yang dapat mempengaruhi motivasi dan prestasi belajar.

Proses belajar membutuhkan keterampilan berkomunikasi. Komunikasi dianggap sebagai suatu proses dua arah dimana peserta didik harus mampu mengkomunikasikan ide-ide matematika mereka serta memahami komunikasi matematis orang lain. Komunikasi adalah penting untuk ilmu pengetahuan. Jika dihubungkan dengan keterampilan, komunikasi akan menjadi keterampilan yang penting atau keterampilan dasar. Para ilmuwan harus menguasai keterampilan ini dalam mengkomunikasikan temuan dan ide-ide dengan peserta didik (Levi, 2009).

Menurut The Organisation for Economic Co-operation and Development (OECD) keterampilan berkomunikasi termasuk mengekspresikan diri dalam berbagai cara, secara lisan maupun dalam bentuk tertulis, serta memahami secara lisan maupun tertulis isi dari penyataan orang lain. Keterampilan berkomunikasi menjadi sangat penting karena setiap orang mempunyai kebutuhan untuk mengemukakan ide, membantu dalam proses penyusunan pikiran, juga merupakan dasar untuk memecahkan masalah. Membangun komunikasi matematika menurut National Center Teaching dalam Sukisno (2009) dapat memberikan manfaat sebagai berikut: 1) memodelkan situasi dengan lisan, tertulis, gambar, grafik, dan secara aljabar; 2) merefleksi dan mengklarifikasi dalam berpikir mengenai gagasan matematika dalam berbagai situasi; 3) mengembangkan pemahaman terhadap gagasan matematika termasuk peranan definisi dalam matematik; 4) menggunakan keterampilan membaca, mendengar, dan menulis untuk menginterpretasikan dan mengevaluasi gagasan matematika; 5) mengkaji gagasan matematika melalui konjektur dan alasan yang meyakinkan; dan 6) memahami nilai dari notasi dan peran matematika dalam pengembangan gagasan matematika.

Hasil akhir dari keseluruhan proses belajar adalah prestasi belajar. Menurut Winkel (1991) prestasi belajar merupakan bukti keberhasilan yang telah dicapai peserta didik yang mana setiap kegiatan belajar dapat menimbulkan suatu perubahan yang khas. Pencapaian tujuan pembelajaran 
yang berupa prestasi belajar merupakan hasil dari kegiatan belajar mengajar semata (Arikunto, 2002).

Dengan kata lain, kualitas kegiatan belajar mengajar adalah satu-satunya faktor penentu bagi hasil belajar. Pada umumnya tes hasil belajar menilai apa yang diperoleh setelah peserta didik itu di beri suatu pelajaran. Pada penyusunan tes hasil belajar usaha-usaha dilakukan untuk menentukan pengetahuan dan keterampilan yang sudah diajarkan di berbagai tingkat pendidikan, dan butir-butir tes disusun untuk penilaian ketercapaiannya.

\section{METODOLOGI}

Penelitian dilakukan berdasarkan periode tutorial online program non Pendas yaitu pada tanggal 14 Maret 2011 sampai dengan 8 Mei 2011, dengan menggunakan fasilitas tutorial online Univesitas Terbuka. Variabel pada penelitian ini adalah prestasi belajar (variabel dependen), motivasi (variabel independen), keterampilan berkomunikasi (variabel independen)

Populasi dalam penelitian ini adalah mahasiswa program Non Pendas FKIP-UT yang mengikuti tutorial online. Tutorial online ini merupakan layanan bantuan belajar, sehingga jumlah sampel ditentukan setelah tutorial selesai. Mahasiswa yang dipilih sebagai sampel adalah mahasiswa Non Pendas Universitas Terbuka yang mengikuti tutorial dari awal sampai akhir yang dapat dilihat dari pengerjaan tes awal dan tes akhir serta kelengkapan tugas yang dikirimkan. Berdasarkan kriteria tersebut terpilih sebanyak 36 orang mahasiswa dengan program studi dan wilayah yang berbeda. Untuk selanjutnya hasil tes akhir digunakan untuk variabel prestasi belajar mahasiswa.

Analisis regresi yang digunakan untuk mengetahui pengaruh motivasi dan keterampilan berkomunikasi terhadap prestasi belajar mahasiswa. Adapun model populasi hubungan linier regresi adalah $Y=\beta_{0}+\beta_{1} X+\varepsilon$. Hipotesis yang diuji adalah:

$H_{0}: \beta_{1}=0$ [variabel indipenden (motivasi atau keterampilan berkomunikasi) tidak berpengaruh terhadap prestasi belajar].

$H_{1}: \beta_{1} \neq 0$ [variabel indipenden (motivasi atau keterampilan berkomunikasi) berpengaruh terhadap prestasi belajar].

Setelah ditaksir dengan menggunakan teorema statistika kuadrat terkecil (ordinary least square) terhadap model linear regresi diperoleh taksiran persamaan regresi $\hat{Y}=a+b X$.

Sedangkan untuk mengetahui pengaruh motivasi dan ketrampilan berkomunikasi terhadap prestasi belajar dengan model linear $Y=\beta_{0}+\beta_{1} X_{1}+\beta_{2} X_{2}+\varepsilon$. Analisis untuk mengetahui pengaruh motivasi $\left(X_{1}\right)$ dan ketrampilan berkomunikasi $\left(X_{2}\right)$ sebagai variabel independen terhadap prestasi belajar $(Y)$ sebagai variabel dependen, digunakan uji statistik regresi linier ganda dengan hipotesis sebagai berikut.

$\mathrm{H}_{0}: \quad \beta=0$ (motivasi dan keterampilan berkomunikasi tidak berpengaruh terhadap prestasi belajar).

$\mathrm{H}_{1}: \quad \beta \neq 0$ dengan $\beta=\left(\begin{array}{l}\beta_{1} \\ \beta_{2}\end{array}\right)$ (motivasi dan keterampilan berkomunikasi berpengaruh terhadap prestasi belajar). 
Setelah ditaksir dengan menggunakan teorema statistika kuadrat terkecil (ordinary least square) terhadap model linear regresi diperoleh taksiran persamaan regresi $\hat{Y}=a_{0}+a_{1} X_{1}+a_{2} X_{2}$. Analisis regresi sederhana dan linear ini dioleah dengan menggunakan SPSS 16.

\section{HASIL DAN PEMBAHASAN}

\section{Pengaruh motivasi terhadap prestasi belajar}

Kegiatan akhir pertemuan mahasiswa diminta mengisi angket secara online. Tujuan dari pengisian angket ini adalah untuk mengetahui motivasi mereka selama mengikuti tutorial. Ada 35 butir yang dikembangkan, dan terdapat 9 nomor yang memiliki pernyataan negatif.

Tabel 1. Motivasi selama mengikuti tutorial online

\begin{tabular}{lccccc}
\hline \multirow{2}{*}{ Kondisi } & \multicolumn{5}{c}{ Persentase } \\
\cline { 2 - 6 } & $\mathbf{5}$ & $\mathbf{4}$ & $\mathbf{3}$ & $\mathbf{2}$ & $\mathbf{1}$ \\
\hline Perhatian (Attention) & $23 \%$ & $38 \%$ & $15 \%$ & $16 \%$ & $8 \%$ \\
Relevansi (Relevance) & $23 \%$ & $43 \%$ & $16 \%$ & $12 \%$ & $6 \%$ \\
Percaya diri (Confidence) & $26 \%$ & $39 \%$ & $16 \%$ & $11 \%$ & $8 \%$ \\
Kepuasan (Satisfaction) & $29 \%$ & $41 \%$ & $11 \%$ & $11 \%$ & $7 \%$ \\
\hline
\end{tabular}

Instrumen yang masuk ke dalam kategori relevansi (relevance) mendapatkan hasil yang cukup besar untuk jawaban positif dari mahasiswa. Data pada Tabel 1 terlihat lebih dari $66 \%$ mahasiswa memberikan pernyataan positif untuk pertanyaan yang berisi tentang bagaimana motivasi mahasiswa berkaitan dengan kegiatan tutorial online yang dihubungkan dengan kehidupan seharihari sebagai guru. Berdasarkan hasil tersebut dapat diindikasikan bahwa tutorial online berbasis pendekatan kontekstual ini tepat untuk diterapkan karena dapat memotivasi mahasiswa untuk mengikuti tutorial online dengan menghubungkan materi dengan kehidupan sehari-hari.

Hal tersebut sejalan dengan pernyataan Libman (2010) yang menyatakan bahwa dalam proses pembelajaran peserta didik harus benar-benar menganggap masalah yang dipelajari sebagai masalah mereka sendiri. Hal ini akan menyebabkan mereka mengevaluasi, mempelajari konsep dan prinsip, yang berguna untuk memotivasi peserta didik dalam membangun, mengubah, dan merekonstruksi konsep mereka sebelumnya. Asumsinya adalah bahwa jika peserta didik bekerja untuk diri mereka sendiri dan memiliki gagasan yang jelas tentang konteks pengetahuan yang relevan, mereka akan berusaha untuk memperoleh pengetahuan tersebut.

Hasil penelitian yang menunjukkan motivasi yang tinggi dalam mengikuti tutorial online tidak searah dengan penelitian yang dilakukan Susanti (2007). Motivasi yang rendah terlihat dalam pelaksanaan tutorial online, yang tercermin dari rendahnya partisipasi mahasiswa. Susanti (2007) menghubungkan motivasi dengan kemampuan penggunaan teknologi pembelajaran yang rendah pada mahasiswa. Rendahnya partisipasi mahasiswa dalam tutorial online juga berhubungan dengan tingkat kesibukan dimana semua mahasiswa adalah sudah bekerja. Kesibukan mahasiswa tersebut mengakibatkan mahasiswa tidak mampu menyediakan waktunya secara cukup untuk mengakses tutorial online.

Selanjutnya data diolah untuk mengetahui pengaruh motivasi terhadap prestasi belajar dengan menggunakan SPSS 16, dari uji regresi tersebut diperoleh persamaan $y=-116.506+$ 1.769x. Dengan nilai sig sebesar 0\%. Nilai tersebut kurang dari 5\%. Sehingga $\mathrm{H}_{0}$ ditolak. Jadi 
persamaan regresi persamaan regresi linier yang berarti motivasi berpengaruh terhadap prestasi belajar.

Selanjutnya untuk mengetahui besarnya pengaruh yang diperoleh. Nilai koefisien determinasi dapat dilihat pada nilai $\mathrm{R}$ Square didapat 0,887 =88,7\%. Nilai tersebut menunjukkan bahwa motivasi mempengaruhi prestasi belajar sebesar $88,7 \%$. Hasil penelitian ini sejalan dengan McClelland (dalam Sfenrianto, 2009) yang menjelaskan bahwa motivasi mempunyai kontribusi sampai 64\% terhadap prestasi belajar. Sedangkan studi yang dilakukan Fyans dan Maerh (1987) menunjukkan bahwa di antara tiga faktor, yaitu motivasi, latar belakang keluarga dan kondisi sekolah, maka faktor motivasi lebih dominan mempengaruhi prestasi belajar. Selain itu beberapa peneliti (Tella, 2007; McKeachie \& Svinicki, 2006) juga menunjukkan bahwa terdapat pengaruh yang signifikan antara motivasi dengan prestasi belajar peserta didik.

Ames (1992) menyatakan bahwa motivasi yang tinggi sangat dibutuhkan dalam E-learning. Sedangkan Coccea (2010) menunjukkan motivasi berpengaruh besar terhadap kualitas pembelajaran mealui E-learning. Keller (2000) menyatakan bahwa motivasi yang tinggi sangat penting dalam pemanfaatan E-learning. Selain itu Keller (2000) menambahkan peran tutor sangat berpengaruh terhadap motivasi peserta didik dalam belajar.

Di Indonesia terdapat penelitian yang berkaitan dengan motivasi peserta didik terhadap hasil belajar. Harjo dan Badjuri (2000) dalam penelitiannya tentang pengaruh motivasi terhadap prestasi belajar siswa SD, menemukan bahwa: 1) terdapat pengaruh yang signifikan antara motivasi berprestasi dengan prestasi belajar siswa, 2) terdapat pengaruh yang signifikan antara cara belajar dengan prestasi belajar siswa, dan 3) terdapat pengaruh yang signifikan antara motivasi dan cara/kebiasaan belajar dengan prestasi belajar siswa.

Dengan demikian dapat disimpulkan bahwa untuk meningkatkan motivasi mahasiswa diperlukan suatu metode yang tepat agar mahasiswa bersedia meluangkan waktunya untuk tetap berpartisipasi dalam tutorial online. Tutorial online berbasis pendekatan kontekstual telah mampu meningkatkan motivasi mahasiswa karena telah menjadikan tutorial ini menjadi kebutuhan bagi mahasiswa. Dengan menghubungkan materi dengan data yang dimilikinya akan memudahkan mahasiswa dalam penguasaan materi.

\section{Pengaruh Keterampilan Berkomunikasi terhadap Prestasi Belajar}

Kriteria pengamatan atas keterampilan berkomunikasi terdiri dari 20 butir dan diamati oleh dua orang pengamat. Untuk mengamati keterampilan berkomunikasi mahasiswa, pengamat mengamati aktivitas mahasiswa pada saat tutorial berlangsung. Mereka juga menelaah portofolio yang merekam semua kegiatan peserta tutorial online. Partisipasi mahasiswa dan diskusi yang diikuti merupakan contoh faktor yang diamati untuk mengukur keterampilan berkomunikasi selain itu pengamat juga mengamati tiga tugas yang dikerjakan mahasiswa.

Skor paling tinggi diperoleh untuk indikator memecahkan masalah. Secara lebih spesifik, skor yang paling tinggi diperoleh untuk indikator "terampil menuliskan jawaban dengan langkah yang tepat" yaitu sekitar 88\%. Hal tersebut menunjukan bahwa sebagian besar mahasiswa sudah terampil menuliskan jawaban dengan langkah yang tepat. Hasil tersebut dapat terlihat ketika mahasiswa mengerjakan tugas dengan langkah yang jelas dan runtut berdasarkan rumus-rumus yang tepat. Sekitar 27\% jumlah skor diberikan pengamat untuk indikator "Terampil menyimpulkan hasil diskusi dan pembahasan". Skor yang diberikan pengamat rendah karena jarang sekali mahasiswa menyimpulkan hasil diskusi dari setiap pertemuan, walaupun tutor sudah meminta mahasiswa untuk melakukan hal tersebut. 
Tabel 2. Persentase Indikator Keterampilan Berkomunikasi

\begin{tabular}{lccccc}
\hline \multirow{2}{*}{ Kondisi } & \multicolumn{5}{c}{ Persentase } \\
\cline { 2 - 6 } & $\mathbf{5}$ & $\mathbf{4}$ & $\mathbf{3}$ & $\mathbf{2}$ & $\mathbf{1}$ \\
\hline Menerjemahkan masalah kedalam masalah matematika & $69 \%$ & $4 \%$ & $0 \%$ & $7 \%$ & $19 \%$ \\
Mengkomunikasikan berfikir matematika secara koheren & $47 \%$ & $1 \%$ & $17 \%$ & $8 \%$ & $26 \%$ \\
Menganalisis dan menilai berfikir matematik orang lain & $56 \%$ & $3 \%$ & $0 \%$ & $0 \%$ & $42 \%$ \\
Menulis pertanyaan dan menggali informasi & $25 \%$ & $0 \%$ & $29 \%$ & $0 \%$ & $46 \%$ \\
Membagi fikiran, informasi dan penemuan kepada orang lain & $42 \%$ & $0 \%$ & $0 \%$ & $17 \%$ & $42 \%$ \\
Mengeluarkan dan mempertajam ide & $58 \%$ & $8 \%$ & $3 \%$ & $2 \%$ & $29 \%$ \\
Memecahkan masalah & $75 \%$ & $1 \%$ & $11 \%$ & $8 \%$ & $4 \%$ \\
Memodelkan situasi dalam bentuk diagram, grafik dan aljabar & $66 \%$ & $0 \%$ & $18 \%$ & $0 \%$ & $15 \%$ \\
Menuliskan peranan definisi matematika & $58 \%$ & $0 \%$ & $0 \%$ & $0 \%$ & $42 \%$ \\
Menyimpulkan & $17 \%$ & $11 \%$ & $0 \%$ & $0 \%$ & $72 \%$ \\
\hline
\end{tabular}

Beberapa penelitian mengenai keterampilan berkomunikasi mendukung hasil penelitian ini di antaranya adalah Levi (2009). Levi (2009) menyatakan bahwa keterampilan berkomunikasi merupakan keterampilan dasar yang harus dimiliki peserta didik untuk memahami sebuah materi. Keterampilan berkumunikasi yang tinggi akan mempermudah peserta didik untuk berdiskusi, mencari informasi, menganalisis dan mengevaluasi data serta membuat laporan. Sedangkan Mallet (2008) menyatakan bahwa keterampilan berkomunikasi peserta didik dapat diukur melalui diskusi dan pemberian tugas secara online. Namun pada penelitian ini, hal tersebut belum diukur karena belum terbiasanya peserta didik melakukan kegiatan diskusi secara online.

Pada uji pengaruh, persamaan regresi untuk pengaruh keterampilan berkomunikasi terhadap prestasi belajar pada saat mengikuti tutorial online adalah $y=36,618+0,532 x$. Nilai Sig $=.000=0 \%<$ $5 \%$. maka $\mathrm{H}_{0}$ ditolak yang berarti keterampilan berkomunikasi berpengaruh terhadap prestasi belajar.

Nilai koefisien determinasi dapat dilihat pada nilai R Square didapat $0,747=74,7 \%$. Dari hasil uji regresi terlihat bahwa keterampilan berkomunikasi mempunyai pegaruh terhadap prestasi belajar yang tinggi yaitu sebesar 74,7\%. Anggapan tersebut tentu saja dapat mematahkan anggapan bahwa keterampilan berkomunikasi tidak dapat dibangun pada pembelajaran matematika (Sukisno, 2009). Anggapan ini tentu saja tidak tepat, karena menurut Greenes dan Schulman (dalam Levi 2009), komunikasi matematika memiliki peran: (1) kekuatan sentral bagi peserta didik dalam merumuskan konsep dan strategi matematika; (2) modal keberhasilan bagi peserta didik terhadap pendekatan dan penyelesaian dalam eksplorasi dan investigasi matematika; dan (3) wadah bagi peserta didik dalam berkomunikasi dengan temannya untuk memperoleh informasi, membagi pikiran dan penemuan, curah pendapat, menilai dan mempertajam ide untuk meyakinkan yang lain.

Beberapa pernyataan tersebut sejalan dengan konstruktivisme sosial yang dipelopori oleh Vygotsky. Konstruktivisme sosial lebih menekankan kepada hubungan antara individu dan masyarakat dalam mengonstruksi pengetahuan. Vygotsky lebih lanjut menekankan bahwa pentingnya interaksi sosial dengan orang lain yang punya pengetahuan lebih baik. Dengan interaksi itu peserta didik dapat mengkonstruksi pengetahuannya sesuai dengan pengetahuan yang dimiliki orang lain yang memiliki pengetahuan lebih baik (Suparno, 1997).

\section{Pengaruh Motivasi dan Keterampilan Berkomunikasi terhadap Prestasi Belajar}

Persamaan regresi untuk Pengaruh Motivasi dan Keterampilan Berkomunikasi adalah $y=-90.291+0.122 x_{1}+1.447 x_{2}$. Dengan nilai Sig $=.000=0 \%<5 \%$. Dari nilai yang didapat maka $\mathrm{H}_{0}$ ditolak yang berarti motivasi dan keterampilan berkomunikasi berpengaruh terhadap prestasi belajar. 
Nilai koefisien determinasi dapat dilihat pada nilai R Square pada Tabel Model Summary didapat $0,897=89,7 \%$. Nilai tersebut menunjukkan bahwa motivasi dan keterampilan berkomunikasi mempengaruhi prestasi belajar sebesar $89,7 \%$.

Uji pengaruh ini bertujuan untuk mencari variabel mana yang dominan mempengaruhi prestasi belajar. Jika dibandingkan dengan hasil yang didapat dari uji pengaruh sebelumnya bahwa pengaruh motivasi terhadap prestasi belajar $(88,7 \%)$, setelah memasukan keterampilan berkomunikasi, keduanya hanya mampu menaikan $\mathrm{R}^{2}$ sebesar $89,7 \%-88,7 \%=1 \%$. Disisi lain variabel keterampilan berkomunikasi berpengaruh terhadap prestasi belajar $(74,7 \%)$. Setelah memasukan variabel motivasi ternyata mampu menaikan nilai $\mathrm{R}^{2}$ sebesar $89,7 \%-74,7 \%=15 \%$. Jadi motivasi memberikan sumbangan lebih dominan dibandingkan dengan keterampilan berkomunikasi terhadap prestasi belajar.

\section{KESIMPULAN DAN SARAN}

Hasil penelitian ini menunjukkan (1) terdapat pengaruh motivasi terhadap prestasi belajar sebesar 88,7\%, (2) terdapat pengaruh keterampilan berkomunikasi terhadap prestasi belajar sebesar $74,7 \%$, (3) terdapat pengaruh motivasi dan keterampilan berkomunikasi terhadap prestasi belajar sebesar $89,7 \%$,

Hasil analisis dengan mengikuti tutorial online berbasis pendekatan kontekstual, terdapat pengaruh motivasi dan keterampilan berkomunikasi mahasiswa terhadap prestasi belajar. Oleh karena itu peneliti memberikan saran kepada tutor untuk menghubungkan materi dengan kehidupan sehari-hari dengan tujuan memotivasi mahasiswa untuk selalu terlibat dalam latihan dan diskusi secara online sehingga keterampilan berkomunikasi mahasiswa meningkat. Dengan demikian tutorial online ini dapat dijadikan solusi yang tepat untuk meningkatkan prestasi belajar mahasiswa.

\section{REFERENSI}

Brown, S. (2001). Campus re-engineering-innovation in open \& distance learning: Successful development of online and web-based learning. London: Kogan Page

Cocea , M. (2010). Motivation Include or Excluded from e-learning. Diambil tanggal 27 ovember 2010 dari: http://citeseerx.ist.psu.edu/viewdoc/download?doi=10.1.1.75.520.

Hanafi. (2008). The applications of e-learning in tutorial process. Jurnal Pendidikan Terbuka dan Jarak Jauh, 9 (1), 24-30.

Hardjo, S. \& Badjuri. (2000). Pengaruh motivasi berprestasi dan cara belajar terhadap prestasi belajar siswa sekolah dasar di Kabupaten Semarang. Jurnal Pendidikan. 1(2):134-143.

Keller, J. (2000). How to integrate learner motivation planning into lesson planning: The ARCS model approach. Paper presented at VII Semanario, Santiago, Cuba.

Levi, O. (2009). Teaching scientific communication skills in science studies: Does it make a difference. International Journal of Science and Mathematics Education. 7, 875-903.

Libman, Z. (2010). Integrating real-life data analysis in teaching descriptive statistics: A constructivist approach. Journal of Statistics Education. 18 (1), 1-25.

Mallet, G. (2008). Asynchronous online collaboration as a flexible learning activity and an authentic assessment method in an undergraduate mathematics course. Eurasia Journal of Mathematics, Science \& Technology Education.

Noviyanti, M. (2006). laporan penelitian kesiapan tutor universitas terbuka dalam memanfaatkan fasilitas tutorial online. Jakarta: Universitas Terbuka 
NCTM. (2000). Principles and standards for school mathematics. USA: The National Council of Teachers of Mathematics, Inc.

OECD. (1999). Measuring knowledge students and skills. France: The Organisation for Economic Co-operation and Development (OECD. Diambil tanggal 23 Februari 2011 dari: http://www.oecd.org/dataoecd/45/32/33693997.pdf.

Pusat Pengujian UT (Pusjian). (2009). Daftar nilai matakuliah statistika pendidikan program pendas dan non pendas. Universitas Terbuka.

Saxena, M. (2010). Learner analysis framework for globalized e-learning. A Dissertation Presented in Partial Fulfillment Of the Requirements for the Degree Doctor of Philosophy Capella University.

Sfenrianto. (2009). Model adaptive r-learning system (AES) berbasis motivasi mahasiswa. Diambil tanggal 13 Februari 2011 dari: www.cs.ui.ac.id/download/71.

Smith, R. (2008). Motivational factors in e-learning. Diambil tanggal 13 Desember 2010 dari: http://www.discreate.org/ruthcsmith/GWU\%20Papers/Motivation.pdf

Soekisno, R. (2009). Membangun keterampilan komunikasi matematika. Tulisan disampaikan pada seminar Internasional di UIN Syarif Hidayatullah Jakarta.

Suparno, P. (2001). Teori perkembangan kognitif jean piaget. Yogyakarta: Kanisius.

Susanti. (2007). Pengaruh faktor internal mahasiswa terhadap partisipasi mahasiswa dalam tutorial online. Jurnal Pendidikan Terbuka dan Jarak Jauh, 8 (1), 68-82.

Tella, A. (2007). The impact of motivation on student's academic achievement and learning outcomes in mathematics among secondary school students in Nigeria. Eurasia Journal of Mathematics, Science \& Technology Education, 3 (2), 149-156.

Trianto. (2009). Mendesain model pembelajaran inovetif-progresif (konsep, landasan, dan implementasinya pada kurikulum tingkat satuan pendidikan (KTSP). Jakarta: Kencana. 